\title{
COMMENTS
}

\section{INTERNATIONAL SPACE LAW}

\author{
MARINA LITS, \\ Tyumen State University (Tyumen, Russia) \\ SERGEI STEPANOV, \\ Tyumen State University (Tyumen, Russia) \\ ANNA TIKHOMIROVA, \\ Tyumen State University (Tyumen, Russia)
}

DOI: 10.21684/2412-2343-2017-4-2-135-155

It is well known that the modern day technologies that drive our global society are highly dependent on the use of outer space. For example, daily activities such as sending emails, making phone calls and carrying out bank transactions cannot be done unless satellite technologies are involved. When you catch a plane, the air traffic control is dependent on GPS. Even natural disaster management is dependent on satellite imaging.

Taking into account the importance of this, it becomes increasingly necessary to be knowledgeable in the field of international law as it is the only sphere of law that reaches beyond the physical boundaries of the Earth, goes deep into space and provides protection for today's society.

With new steps being taken to exploit further the potentials of outer space, and with increasing talk of new space missions and new discoveries, current international space law is being placed under scrutiny, for it should be remembered that the major international legal documents in this field were adopted in the middle of the $20^{\text {th }}$ century, and thus there are fears that the law may have become obsolete, irrelevant in the face of new challenges in the use of outer space.

This paper delivers an analysis of existing international space law and attempts to raise several crucial issues pertinent in the area. 
Keywords: international space law; space activities liability; commercialization of space.

Recommended citation: Marina Lits et al., International Space Law, 4(2) BRICS Law Journal 135-155 (2017).

\section{Basic Principles of International Space Law}

In accordance with the basic principles of international civil law, liability is based in the first place on the laws of the country on whose territory the damage occurs (lex loci delicti). But where the setting extends beyond geographical boundaries and encompasses the realm of outer space, such as when a man-made space object that causes damage in one country originated in another country, litigation may turn out to be extremely laborious. This is because civil law claims may be very difficult to assert for a variety of reasons, e.g. limits of indemnity, problems with regard to the burden of proof, inequality in terms of the strength of the parties involved, and the difficulty of getting court decisions executed. Because of these shortcomings, special rules on liability were established by the United Nations. ${ }^{1}$

But the road to establishing an international regime was quite long. In the late 1950s, an academic debate began as to liability for third-party damage caused by space activities. In 1962, U.S. delegates raised the need for a liability regime before the Legal sub-committee of the UN Outer Space Committee. This was done in response to an event of September 5, 1962, when a 3-kilogram metal object fell from the sky and landed on a street in Manitowoc, Wisconsin, and the United States believed it to be from Sputnik 4, launched into space by the Russians in 1960. Unfortunately, the Soviet Union showed little interest in preparing a draft instrument, as they considered that liability would arise in accordance with international law.

The principle that the state bears international responsibility for national activities in outer space and that each state which launches or procures the launching of an object into space is internationally liable for damage sustained on the Earth, in airspace or in outer space, was set out in special international documents that initiated the origin of international space law.

Space law can be described as the body of law applicable to and governing space-related activities. The term "space law" is most often associated with the rules,

Piotr Manikowski, Examples of Space Damages in the Light of International Space Law, 1(1) The Poznań University of Economics Review (2006) (Apr. 4, 2017), also available at http://www.ebr.edu.pl/ pub/2006_1_54.pdf. 
principles and standards of international law appearing in five international treaties and five sets of principles governing outer space which have been elaborated under the auspices of the United Nations. However, space law also includes international agreements, treaties, conventions, rules and regulations of international organizations as well as national laws, rules and regulations, executive and administrative orders, and judicial decisions.

Since the end of the $20^{\text {th }}$ century, there have been major changes in activities related to the development and study of outer space. The level of commercial use of space has increased significantly, in particular the establishment of satellite communications, launch services and remote data collection. ${ }^{2}$ Private entities are being set up quickly, and they are able to conduct space activities effectively and make a substantial contribution to the development of the space industry.

Amid this activity, it is worth recalling that Art. 38 of the Statute of the International Court of Justice (ICJ) regards "the general principles of law recognized by civilized nations ${ }^{\prime \prime 3}$ as one of the applicable sources accepted as law. Thus it not surprising that the general principles of international space law play a huge and growing role. They are becoming even more crucial, considering that talk of new explorations (and, sometimes, appropriation) of a number of different celestial bodies, such as the moon and Mars, abounds.

There are many principles of international space law. In our view, three of them are of key importance: transparency, cooperation and reciprocity.

Transparency can be summarized as "a clean window that you can look through.". In 1998, the UN General Assembly considered that Member States should pay more attention to the critical problem of collisions of space objects ${ }^{5}$ and stressed the important role of international cooperation for the exploration and use of outer space for peaceful purposes.

The concept of transparency and confidence-building measures (TCBMs) relating to issues concerning outer space was adopted by the UN, for the first time, via Resolution 60/66, ${ }^{6}$ titled Transparency and Confidence-Building Measures in Outer Space Activities.' Specifically, transparency and confidence-building measures can

2 Fausto Pocar, An Introduction to the PCA's Optional Rules for Arbitration of Disputes Relating to Outer Space Activities, 38 Journal of Space Law 171, 174 (2012) (Apr. 5, 2017), also available at http://www. spacelaw.olemiss.edu/jsl/pdfs/supplements/pocar.pdf.

3 Statute of the International Court of Justice, 33 U.N.T.S. 993, Art. 38, para. 1(c).

4 Ulrich K. Preuß, Transparency in International Law, 12(3) International Journal of Constitutional Law 820,822 (2014).

5 G.A. Res. 52/56, U.N. GAOR $52^{\text {th }}$ Sess., at 6, U.N. Doc A/RES/52/56 (1998).

6 G.A. Res. 60/66, U.N. GAOR, $60^{\text {th }}$ Sess., U.N. Doc. A/RES/60/66 (2005).

7 Jana Robinson \& Vladimir Silhan, Securing Outer Space: A Major Global Challenge, 4 Science for Population Protection 9 (2012). 
actually serve to enable states to better plan their actions without running afoul of existing international law.

Moreover, the UN General Assembly adopted several precise resolutions concerning transparency and confidence-building measures in outer space activities ${ }^{9}$ calling for implementing transparency through relevant national mechanisms.

Thus TCBMs provide a basis for predicting the actions of others and actually allow states to plan their own actions in accordance with relevant technical rules and guidelines such as, for example, the Space Debris Mitigation Guidelines. ${ }^{10}$

Therefore, the principle of transparency is conditio sine qua non for a realistic means of generating a more accountable, peaceful and legitimate form of international relations that encompasses outer space."

As for the principle of cooperation, it remains the key to sustainable activity in outer space. ${ }^{12}$ International cooperation in the exploration and use of space for peaceful purposes needs to be conducted in accordance with the provisions of international law, including the Charter of the United Nations and the Treaty on Principles Governing the Activities of States in the Exploration and Use of Outer Space, including the Moon and Other Celestial Bodies ${ }^{13}$ (Outer Space Treaty), and all states should contribute to promoting and fostering international cooperation. ${ }^{14}$

The UN Charter establishes general rules for Member States aimed at achieving international cooperation in solving international problems in various spheres (Art. 1). Art. III of the Outer Space Treaty applies both international law and the optimum order system of the UN Charter to space activities. ${ }^{15}$

The preamble to the Outer Space Treaty recalls one of the basic principles in international law and urges the state parties "to contribute to broad international co-operation" in different aspects of the exploration and use of outer space.

8 Robert A. Friedman, International Law in the Context of Outer Space Activities, $3^{\text {rd }}$ ASEAN Regional Forum (ARF) Workshop on Space Security, Beijing, China, November 30, 2015, at 3-4.

9 G.A. Res. 68/50, U.N. GAOR, $68^{\text {th }}$ Sess., U.N. Doc. A/RES/68/50 (2013); G.A. Res. 69/38, U.N. GAOR, $69^{\text {th }}$ Sess. U.N. Doc. A/RES/69/38 (2014); G.A. Res. 70/53, U.N. GAOR, $70^{\text {th }}$ Sess., U.N. Doc. A/RES/70/53 (2015).

10 Report of the UN Committee on the Peaceful Uses of Outer Space, $53^{\text {rd }}$ Sess., at 15 , U.N. Doc. A/65/20 (2010).

11 Daniel R. McCarthy \& Matthew Fluck, The Concept of Transparency in International Relations: Towards a Critical Approach, 23(2) European Journal of International Relations 416 (2017).

12 Nicholas D. Welly, Enlightened State-Interest - A Legal Framework for Protecting the "Common Interest of All Mankind" from Hardinian Tragedy, 36 Journal of Space Law 273 (2010).

13 Treaty on Principles Governing the Activities of States in the Exploration and Use of Outer Space, including the Moon and Other Celestial Bodies, entered into force on October 10, 1967, 18 U.S.T. 2410, 610 U.N.T.S. 205.

14 Declaration on International Cooperation in the Exploration and Use of Outer Space for the Benefit and in the Interest of All States, adopted on December 13, 1996, U.N. GAOR $51^{\text {st }}$ Sess., U.N. Doc A/ $\mathrm{RES} / 51 / 122$ (2015).

15 Rex Zedalis \& Catherine Wade, Anti-Satellite Weapons and the Outer Space Treaty of 1967, 8 California Western International Law Journal 454, 457 (1978). 
Even more, states have the duty to cooperate with one another in accordance with the UN Charter. ${ }^{16}$ The abovementioned principle refers to all types of cooperation, including governmental and non-governmental, commercial and noncommercial, global as well as regional. ${ }^{17}$

The rule pacta sunt servanda, established by the 1969 Vienna Convention on the Law of Treaties ${ }^{18}$ (Art. 26), was of prime importance and a secure foundation for peaceful international relations. ${ }^{19}$ A substantive idea of pacta sunt servanda is that if any treaty is in force for the State Party, it is obligatory and must be carried out in good faith (bona fides).

Even the International Law Commission identified a staccato statement ${ }^{20}$ in order to stress the essential importance of pacta sunt servanda. The provision is forcefully yet elegantly drafted, containing no exceptions or conditions which could lead to debate calling into question its validity. ${ }^{21}$

The Group of Governmental Experts on TCBMs in Outer Space Activities encourages states to consider using existing consultative mechanisms, for example, those provided for in Art. IX of the Outer Space Treaty. ${ }^{22}$

Under Art. IX of the Outer Space Treaty, a State Party has the obligation to undertake appropriate international consultations if its planned activity in outer space can potentially cause harm to activities of other State Parties in the peaceful exploration of space before it proceeds with any such activity.

Reciprocity, as another major principle of international space law, is important enough to be considered a meta-rule of the system of international law - an essential element in its functioning. ${ }^{23}$

The principle of reciprocity contains the idea that each party has rights and duties ${ }^{24}$ and can resolve many issues under international law.

16 G.A. Res. 25/2625 (XXV), Declaration on Principles of International Law concerning Friendly Relations and Co-operation among States in accordance with the Charter of the United Nations, U.N. GAOR, $25^{\text {th }}$ Sess., U.N. Doc. A/RES/25/2625 (1970).

17 Sergio Marchisio, Article IX in Cologne Commentary on Space Law, Vol. I: Outer Space Treaty 172 (S. Hobe et al. (eds.), Cologne: Carl Heymans, 2009).

18 Vienna Convention on the Law of Treaties (VCLT), entered into force on May 23, 1969, UN Doc A/ Conf.39/27; 1155 U.N.T.S. 331; 8 I.L.M. 679 (1969); 63 AJIL 875.

19 Report of the Committee of the Whole, United Nations Conference on the Law of Treaties on the work of its $1^{\text {st }}$ Sess., $29^{\text {th }}$ meeting of the Committee of the Whole, at 157, U.N. Doc. A/CONF.39/14.

20 Revision of Part II of the Draft Articles in the Light of the Comments of Governments in Yearbook of International Law Commission. Vol. II 60 (New York: United Nations, 1966).

21 Mark E. Villiger, Commentary on the 1969 Vienna Convention on the Law of Treaties 368 (Leiden and Boston: Martinus Nijhoff Publishers, 2009).

22 Report of the Group of Governmental Experts on Transparency and Confidence-Building Measures in Outer Space Activities, U.N. GAOR 68 ${ }^{\text {th }}$ Sess., at 20, U.N. Doc A/68/189, (2013).

23 Francesco Paris \& Nita Ghei, The Role of Reciprocity in International Law, 36(1) Cornell International Law Journal 93, 94 (2003).

24 Alvin W. Gouldner, The Norm of Reciprocity: A Preliminary Statement, 25(2) American Sociological Review 161, 169 (1960). 
Art. IX of the Outer Space Treaty formulates the principle of reciprocity or mutual assistance and provisions about the need for international consultations in case of potentially harmful interference in outer space.

Having commented on the above-said principles, it is important to underline their crucial role when a state engages in the exploration of celestial bodies. More so, when several countries are involved in this process.

\section{Issue of Responsibility in Space}

Governmental bodies frequently enter into agreements with private entrepreneurs that ensure the efficient use of resources of both partners and facilitate commercial activities with high potential for economic growth. For instance, the USA supports the development of commercial space projects in the fields of transportation and manned space activities in the framework of National Aeronautics and Space Administration (NASA) competence. ${ }^{25}$

The commercialization process flowing in this area was not taken into account during the drafting and adoption of major international treaties on outer space activities. In this regard, a number of issues concerning the regulation of commercial companies remain open, in practice there are gaps in the law. According to the existing regime, the state is responsible for the activities of legal persons in their territories, but it does not clarify matters where the launch of a space object occurs from the neutral waters of the ocean.

At this moment, the question of the responsibilities of commercial companies under international space law is acute and requires immediate resolution. Scientists worldwide also support this point of view. Professor Frans G. von der Dunk considers private-sector participation has become a permanent and particular feature of the present level of the development of commercial opportunities in outer space. At the same time, based on historical practice, private enterprises are not mentioned in international treaties. Relatively recently, legal entities were granted independent legal status in the framework of the International Telecommunication Union, along with its decisive role in the coordination of orbital points, the orbits and frequencies for satellite communications operators. The state is obligated to apply international space law norms to those kinds of organizations, in accordance with Art. 6 of the Outer Space Treaty. ${ }^{26}$ Therefore, the issue of rights, obligations and responsibilities of private enterprises remains valid.

25 NASA: Introduction - Commercializing Space (Apr. 6, 2017), available at www.nasa.gov/externalflash/ commercializingspace/.

26 Frans G. von der Dunk, Space for Dispute Settlement Mechanisms - Dispute Resolution Mechanisms for Space? A Few Legal Considerations, at 444-448 (Apr. 4, 2017), available at http://digitalcommons.unl. edu/cgi/viewcontent.cgi?article=1037\&context=spacelaw. 
It is worth noting that during the adoption of the Outer Space Treaty the USA and the Soviet Union took opposite positions in reference to the possibility of private enterprise activity in space. Striking a happy medium, the countries should have included in the Treaty fundamental principles of international law, which envision international responsibility for national activities in outer space regardless of whether they are carried out by governmental bodies or non-governmental entities. In this way, an international treaty does not regard legal entities as the subjects of international space law and the organization's responsibility for the activities rests solely with the state while not denying the possible participation of the private sector in space.

Legal disputes encompassed by international space law between a state and a private enterprise are resolved exclusively at the national level. When a dispute arises between two private companies, the question remains treatment in compliance with international standards; however, those kinds of disputes should be resolved in accordance with national legislation and in national courts.

To cite an instance, the legal dispute between the legal entities Martin Marietta and Intelsat could be mentioned. In August 1987, Intelsat concluded a contract with Martin Marietta to launch two of Intelsat's satellites. The launch of the first satellite was unsuccessful, it failed to establish in a particular orbit. Martin Marietta filed a lawsuit in order to get the declared decision to release them from liability. Intelsat put forward a counterclaim, citing a breach of contract, grievous dereliction of duty and misrepresentation by Martin Marietta.

In the reasoning in the decision of the court, the circumstances did not require the imposition of a specific obligation to take special care in excess of the contract; therefore, a misrepresentation was excluded. When considering the case, it was noted that the state policy of the country requires a person's understanding that if they appeal to a licensed space launch service, they so rely at their own risk. ${ }^{27}$

Most space law experts in the field of public international law consider that this branch of law presumes two forms of liability. As a rule, the literature on international law includes such kinds of international legal responsibility as political responsibility and financial liability.

Political responsibility brings about the result of a breach of any international legal obligation - the international law principle, contractual rules that protect the interests of the other state. Political responsibility arises even if the offense did not result in property damage or other obvious negative consequences. The tort is the basis for raising the international responsibility question of the directly affected state(s) ${ }^{28}$

In this regard, it is evident that legal entities could not be politically responsible. However, we assume that in the future commercial companies may also violate

27 Martin Marietta Corp. v. Intelsat, 763 F. Supp. 1327 (D. Md. 1991) (Apr. 9, 2017), available at http://law. justia.com/cases/federal/district-courts/FSupp/763/1327/1586244/.

28 Малков С.П. Международное космическое право: Учебное пособие [Sergey P. Malkov, International Space Law: Textbook] 344 (St. Petersburg: SUAl, 2002). 
the norms of international space law. For example, if an enterprise inserts into orbit around the Earth any objects carrying nuclear weapons or any other sorts of weapons of mass destruction. In our opinion, in this case the state should act as a representative of the non-governmental entity and then hold them accountable, but in accordance with its domestic law.

At the same time, if the government ignores violations of international space law committed by a legal entity on its territory, it is advisable to provide and apply the political responsibility for the state by means of implementing a satisfaction or a limitation of sovereignty.

The 1972 Convention on International Liability for Damage Caused by Space Objects (Liability Convention) ${ }^{29}$ identifies two types of financial liability: absolute responsibility and liability depending on fault.

In respect of the first type of responsibility, a state bears absolute liability for damage caused by its space object on the surface of the Earth or to an aircraft in flight. The established strict liability principle seems to be reasonable, as there is always a risk of people's death and property or environmental damage, etc. In this regard, it is obvious that no space activity operator could guarantee damage compensation entirely on its own; therefore, public relations in this sphere are raised at the international level.

In order to resolve such disputes, the Claims Commission has been established based on the Liability Convention. In its structure and name, the Claims Commission is similar to the interstate Claims Commission, set up from time to time, in the capacity of the arbitration courts. The aim of the establishment of a Claims Commission was to adjudicate on disputes and (or) on damage claims in the postwar period.

Nevertheless, the demand for the existence of the Claims Commission based on the Liability Convention is controversial due to the fact that the Commission's decisions are not binding as long as both parties agree to it. For the more than forty-year history of the Liability Convention, the Claims Commission has not adjudicated any disputes. ${ }^{30}$

We believe that states need to develop domestic legal acts that establish the procedure for making recourse to state requirements for private enterprises that caused actual damage. This approach is justified by the principle of doing business at your own risk. It seems appropriate to allow states to reduce their financial risk in the event of damage caused by a company in terms of private-sector development.

In practice, space disputes are resolved on the basis of domestic legislation most successfully. For example, in 1993 a decision on pecuniary compensation was issued in favor of the Hughes Corporation in Hughes Communications Galaxy, Inc., v. the United States. On December 5, 1985, Hughes concluded an agreement with the

29 Convention on International Liability for Damage Caused by Space Objects, entered into force on October 9, 1973, 24 U.S.T. 2389, 961 U.N.T.S. 187.

30 Henry R. Hertzfeld, A Roadmap for a Sustainable Space Legal Regime, at 7 (Apr. 9, 2017), available at https://www.gwu.edu/ spi/assets/docs/Hertzfeld-IISL\%20Paper-Revision\%2011-30-2012.pdf. 
U.S. government in the form of the National Aeronautics and Space Administration. NASA had agreed to launch ten Hughes commercial satellites under its programs. However, on October 30,1986, NASA informed Hughes that it could not provide the launch of the satellites, in accordance with the President's announcement earlier that year ending commercial satellite launches by NASA on space shuttles following the Challenger explosion. ${ }^{31}$

The recourse claim procedure is already provided in the legislation of some countries. According to Art. 15 of Belgium's law "On the Launch and Control of Space Objects," the state has a right to commence a counterclaim against an operator; a value of the matter in controversy is limited in the extent of compensation based on this Article. However, if the operator violated the conditions of the permit, he must compensate the damage in full. ${ }^{32}$

The second type of responsibility is contained in Art. III of the Liability Convention:

In the event of damage being caused elsewhere than on the surface of the Earth to a space object of one launching State or to persons or property on board such a space object by a space object of another launching State, the latter be liable only if the damage is due to its fault or the fault of persons for whom it is responsible. ${ }^{33}$

We tend to think that in the context of the commercialization of space activities this norm should be changed - the liability should be laid on the persons who own a space object as a source of increased danger in the framework of civil proceedings. Notably, this approach is used in international nuclear law where the nuclear installation operator bears responsibility for damage resulting from a nuclear incident at the installation.

Moreover, it is also expedient to provide for the possibility of insurance of legal entities that carry out these kinds of activities. The compensation limits for the damage should also be foreseen, as it could be a significant sum of money. Similar limits are provided for in the legislation of a number of countries such as Austria, Belgium, Brazil, the Netherlands, the USA, France and Japan. Particularly, in the Netherlands a legal norm establishes that the requirement applies to a guilty person in full. Nevertheless, if the offender is a licensee, the amount of a counter indemnity cannot exceed the maximum amount of its insurance coverage.

31 Hughes Communications Galaxy, Inc., v. the United States, 998 F.2d 953 (Fed. Cir. 1993).

32 Loi relative aux activités de lancement, d'opération de vol ou de guidage d'objets spatiaux, F. 20053027, 17 Septembre 2005, Le Moniteur Belge, 2e éd., Mercredi 16 Novembre 2005 (Apr. 10, 2017), available at http://download.esa.int/docs/ECSL/Belgium3.pdf.

33 Art. III of the Liability Convention. 
International experience shows that neither air nor space law regulates the insurance at the international level. Space insurance has been available to private enterprises for several years. Especially, it applies to satellites. The insurance reduces the financial risks, thereby attracting new sources of funding for space activities. ${ }^{34}$

Another point worth mentioning when discussing the second type of responsibility in space is that there is no standardized notion of what international fault is (which, in our view, seems ambiguous).

There is the elimination of the principle of absolute liability in the case of damage caused on Earth by a space object of one state to the property of another state. In the case where the damage was caused not on the surface of the Earth, the liability is based on the principle of fault.

Thus, absolute liability is defined owing to the place of damage, where damage is caused on the surface of the Earth or to aircraft in flight. If the damage was caused in outer space, the launching state is liable only in the case where the damage is caused due to the fault of the state. For example, in a 2009 satellite collision (Iridium 33, owned by Iridium Communications, Inc. (USA) and Cosmos 2251, owned by the Russian Space Forces) international responsibility did not take place, because there was no fault of either party. The Iridium/Cosmos collision was settled by the respective countries outside of the Liability Convention. ${ }^{35}$

Some researchers believe that fault is a negligent or intentional failure to act reasonably or according to law or duty. ${ }^{36}$

Due diligence demands to be aware of the risk of harm and to be ready to undertake measures for the prevention of collision. ${ }^{37}$ Violation of the due diligence principle indicates guilt. ${ }^{38}$

The damage could be connected to the initial act only by an unforeseen chain of exceptional circumstances which has occurred because of a combination of causes alien to the author's will and not foreseeable on his part. ${ }^{39}$

Negligence also should be taken into account when determining fault. Negligence is a failure to use reasonable care that results in harm to another party: defined differently, when a party "knew or should have known that its actions would induce

34 Isabella H.P. Diederiks-Verschoor \& Vladimír Kopal, An Introduction to Space Law 113 ( $3^{\text {rd }}$ ed., Alphen aan den Rijn: Kluwer Law International, 2008).

35 Ram Jakhu, Iridium-Cosmos Collision and Its Implications for Space Operations in Yearbook on Space Policy: 2008/2009 259 (K.-U. Schrogl et al. (eds.), Wien and New York: Springer, 2010).

36 Jonathan Wallace \& Susan Ellis Wild, Webster's New World Law Dictionary 141 (Hoboken, NJ: Wiley, 2010).

37 Martha Mejia-Kaiser, Collision Course: 2009 Iridium Cosmos Crash, Published in the Proceedings of the Fifty-Second Colloquium on the Law of Outer Space (2009), at 274.

38 Xue Hanquin, Transboundary Damage in International Law 296 (Cambridge: Cambridge University Press, 2003).

39 Naulilaa Case Decision (Portugal v. Germany), July 31, 1928, II UN RIAA 1031. 
actual infringement.".40 There is widespread recognition that negligence on the part of the claimant is an acceptable exoneration. ${ }^{41}$

The fault referred to in Art. III of the Liability Convention could arise in the shape of two major forms: objective fault and subjective fault. Objective fault refers to the failure to adhere to an international obligation or breach of an obligation imposed by law; ${ }^{42}$ whereas subjective fault refers to the intent or negligence to cause damage. ${ }^{43}$ The majority of writers and the decisions of international tribunals support the objective theory of responsibility. This theory consists of the idea that responsibility is the result of the breach of an international obligation (responsibility without fault). This means that the breach of the duty by result alone leads to responsibility. ${ }^{44}$

Alongside the various theories of responsibility for a wrongful act, there is also the regime of liability without a wrongful act. Here, the causal link between the activity and the damage done leads to the obligation to pay compensation, or liability, even though the damage occurred from a lawful activity. ${ }^{45}$ Examples of such activities are the transportation of oil, the production of nuclear energy and operations in outer space. $^{46}$

Most treaties containing rules on liability concern civil liability, meaning that the operator or owner of a certain activity is obliged to pay compensation for damage resulting from the activity. The liability regarding an accident is restricted to an insurable sum of money and the national courts are the forum for proceedings. The point is that victims should be appropriately compensated and the status quo ante be restored. ${ }^{47}$

In nuce, Art. XII of the Liability Convention provides that the compensation which the launching state will be liable to pay for damage will be determined in accordance with international law and the principles of justice and equity, in order to restore the condition that existed prior to the damage.

40 Commil USA, LLC v. Cisco Systems, Inc., 135 S. Ct. 1920 (No. 13-896) 4 (2015).

41 Stanley Mazaroff, Exonerations from Liability for Damage Caused by Space Activities, 54(1) Cornell Law Review 71, 81 (1968).

42 Lesley J. Smith \& Armel Kerrest, Article VII in Cologne Commentary on Space Law, Vol. I: Outer Space Treaty 141 (S. Hobe et al. (eds.), Cologne: Carl Heymans, 2009).

43 Frans G. von der Dunk, Liability Versus Responsibility in Space Law: Misconception or Misconstruction?, Published in the Proceedings of the Thirty-Fourth Colloquium on the Law of Outer Space (1992), at $363,364$.

44 Maria Flemme, Due Diligence in International Law, Master Thesis, Faculty of Law, University of Lund (Spring 2004).

45 Id. at 10.

46 Göran Lysén, State Responsibility and International Liability of States for Lawful Acts: A Discussion of Principles 135-137 (Gothenburg, Sweden: lustus Förlag, 1997).

47 Flemme 2004, at 11. 
Having said this, it is important to realize that finding guilt in cases regulated by space law is difficult. Apart from the absence of a notion of fault some other issues must be taken into consideration. For example, the damage (and, subsequently, responsibility) may be caused by unforeseen space events (ejections of solar wind, communications problems between installations on Earth and the space object, etc.). This shows how crucial it really is to finally formalize a definition of guilt and aspects of its application in space law matters.

The private sector that carries out space activities is itself also a solid reason for the revision of the basic norms of international treaties. We suggest that the inclusion of legal persons among the number of international space law subjects as well as their rights, obligations and responsibilities would facilitate the creation of a sustainable legalized market in the space industry, thereby reducing the risk of human rights and business violations.

\section{Understanding of Appropriation in Space}

With respect to the problem of subject matter, the prohibition of national appropriation relates clearly to "outer space, including the moon and other celestial bodies."The Outer Space Treaty is silent on the question of what outer space is, what it encompasses and what its boundaries are in relation to airspace. The only statement contained in the Treaty is that the moon and other celestial bodies are included in outer space. For this reason, the prohibition regarding national appropriation would unquestionably extend to the moon and other celestial bodies. Whether or not the prohibition would extend to outer space in its totality or only to part of it, or would relate to the moon or a celestial body as a whole or only to a part of it, are further significant questions. By common sense interpretation, the prohibition could not very well relate to outer space as a whole since no one could at present appropriate outer space as a whole, but only a part of it. Insofar as the moon and other celestial bodies are concerned, the prohibition could extend to the whole entity if national appropriation of the whole is indeed possible. But even in relation to the moon and other celestial bodies, it would appear by reasonable interpretation that the prohibition would also cover acquisition of a part of the moon or other celestial body. Any contrary interpretation would seem to make the prohibition of national appropriation largely illusory.

In relation to national acquisition of a part of outer space, further questions may be raised. For example, does the prohibition extend to the collection of dust particles or other special elements during flight in outer space? Does the prohibition extend to the appropriation of cosmic rays, gases or the sun's energy, or to the collecting of mineral samples or precious metals on the moon or other celestial bodies? Should the answer depend on the type of resource involved, or on its availability in unlimited (cosmic rays, gases) or limited (minerals, metals) quantities, or perhaps on its location? 
In attempting to give answers to these questions, it may be pointed out, first of all, that in the absence of a few special circumstances, little would be gained by insisting on the non-appropriation of resources such as cosmic rays or gases, which are available in inexhaustible quantities. At the same time, the Treaty as it stands seems to make little allowance for national acquisition of exhaustible space resources.

With respect to location, it could be argued that if any parts of outer space, including the moon and other celestial bodies, were found on the Earth, they would not be subject to the prohibition of national appropriation, since they would become part and parcel of the Earth. Under a strict interpretation, it may also be argued that the prohibition extends to the resource irrespective of its location. However, it might be preferable to distinguish between elements of outer space which have reached the Earth as a result of natural causes and those which have done so through human intervention. In the first instance, national appropriation would not be prohibited, whereas in the second example the prohibition would apply. Thus, a meteorite falling to Earth could be appropriated whereas a precious stone or metal brought to the Earth from outer space could not be a subject of national appropriation.

Regarding the jurisdictional boundaries of outer space, particularly the dividing line between airspace and outer space, we seem to know little. Today, after decades of experiments in space, it can be said that an international custom seems to have sprung up which regards the area where space instrumentalities move in durable orbit as outer space. From this we also take for granted that anything above and beyond this area is also regarded as outer space. However, the more precise boundary line between airspace and outer space is still left undetermined.

\section{Different Views on the Possibility of Appropriation in Space}

One of the most talked about questions in international space law in recent years concerns the legal possibility of possession in space, including territories and resource extraction on celestial bodies.

The Declaration of Legal Principles Governing the Activities of States in the Exploration and Use of Outer Space declares that outer space is "not subject to national appropriation by claim of sovereignty, by means of use or occupation, or by any other means" (para. 3). ${ }^{48}$

The Outer Space Treaty (in Art. I) insists the exploration and use of outer space will be carried out for the benefit and in the interests of all countries and for the province of all mankind.

48 Declaration of Legal Principles Governing the Activities of States in the Exploration and Use of Outer Space, GA Res. 1962 (XVIII), UN GAOR, $18^{\text {th }}$ Sess., $1280^{\text {th }}$ Mtg., UN Doc. A/RES/18/1962 (1963). 
At the U.S. Senate Committee on Foreign Relations the term "province of all mankind" has been interpreted as equivalent to "benefit of all mankind" related to the exploration and use of outer space. ${ }^{49}$ The concept of the "province of all mankind" does not appear in the Outer Space Treaty; however, some scholars have concluded that the word "mankind" is meant to denote:

(1) all States;

(2) all States, particularly developing States;

(3) all nations;

(4) all living human beings; or

(5) all living and future human beings. ${ }^{50}$

Art. Il of the Outer Space Treaty declared such an important rule of the space law system as the principle of non-appropriation.

According to the non-appropriation principle, or res communis omnium, certain property is the common heritage of mankind, owned by everyone and by no one. To conclude, specific property rights in celestial bodies cannot exist. ${ }^{51}$

Thus, the Outer Space Treaty excludes from application to the domain of space the traditional modalities of acquisition of unclaimed territory. ${ }^{52}$

Common interest requires states to refrain from giving their individual interests precedence over that of mankind..$^{53}$

While the exercise of gathering samples is not different from the collection of lunar rocks during the Apollo Program missions of the United States, the crucial distinction is that in the case of mineral prospecting, the samples are collected for ultimate private commercial profit rather than public scientific gain. Accordingly, this raises issues as to the lawfulness of such activities in outer space..$^{54}$

Resource extraction can be defined as appropriation because physical matter is being removed from the source and placed in the possession of certain individuals..$^{55}$

There is an opposite view on the matter of appropriation in space, however.

49 Diederiks-Verschoor \& Kopal 2008, at 25.

50 David Tan, Towards a New Regime for the Protection of Outer Space as the "Province of All Mankind," 25(1) Yale Journal of International Law 145, 162 (2000); Ernst Fasan, The Meaning of the Term "Mankind" in Space Legal Language, 2 Journal of Space Law 125, 131 (1974).

51 Nicole Ng, Fences in Outer Space: Recognising Property Rights in Celestial Bodies and Natural Resources, 7 The Western Australian Jurist 143, 149 (2016).

52 Ivan A. Vlasic, The Space Treaty: A Preliminary Evaluation, 55(2) California Law Review 507, 512 (1967).

53 Kemal Baslar, The Concept of the Common Heritage of Mankind in International Law 47 (Dordrecht, The Netherlands: Martinus Nijhoff, 1998).

54 Ricky Lee, Law and Regulation of Commercial Mining of Minerals in Outer Space 13 (New York: Springer Science \& Business Media, 2012).

55 Norry Harn, Commercial Mining of Celestial Bodies: A Legal Roadmap, 27 Georgetown Environmental Law Review 629, 638 (2014). 
Some believe that it is an obligation of all states to consider the legitimate interests of other states in their use of outer space. ${ }^{56}$ The use of outer space is free to the extent that it does not disregard the interests of other states. ${ }^{57}$

Art. I of the Outer Space Treaty establishes the freedom of scientific investigation in outer space and underlines that, "States shall facilitate and encourage international cooperation in such investigation."

Art. III of the Treaty provides that,

States Parties to the Treaty shall carry on activities in the exploration and use of outer space, including the moon and other celestial bodies, in accordance with international law, including the Charter of the United Nations, in the interest of maintaining international peace and security and promoting international in the peaceful exploration and use of outer space. ${ }^{58}$

Art. I of the Treaty lists what has become known as the three freedom principles. The "freedom of access" principle ensures that all mankind will benefit from exploration and use of outer space, despite economic or scientific development, and that outer space "shall be the province of all mankind." In addition, every state will have "freedom of exploration" and free access to all celestial bodies. Finally, all nations have "freedom of use" for scientific investigation, along with a pledge to facilitate cooperation among states.

All people are entitled to equal access to outer space, all people are entitled to live under peaceful skies, and all people are welcome to become equal partners in space exploration. This leaves mankind with the same decision it has always faced: to work together or race against each other in the pursuit of what should be considered a common goal. The challenges of space are already as numerous as the stars; it would be counterproductive to add more obstacles such as a competitive structure. ${ }^{59}$

Currently, two international documents have important implications for property and ownership rights in outer space: the Outer Space Treaty and the Moon Treaty. ${ }^{60}$

56 Ram Jakhu, Legal Issues Relating to the Global Public Interest in Outer Space, 32 Journal of Space Law (2006).

57 Manfred Lachs, The Law of Outer Space 108 (Leiden: Sijthoff, 1972).

58 Kai-Uwe Schrogl \& Julia Neuman, Article VI in Cologne Commentary on Space Law, Vol. I: Outer Space Treaty 70-93 (S. Hobe et al. (eds.), Cologne: Carl Heymans, 2009).

59 Daniel A. Porras, Comment the "Common Heritage" of Outer Space: Equal Benefits for Most of Mankind, 37(1) California Western International Law Journal 143 (2006), Art. 5.

60 Agreement Governing the Activities of States on the Moon and Other Celestial Bodies, opened for signature on December 18, 1979, 1363 U.N.T.S. 3; 18 I.L.M. 1434 (1979). 
Together, the Outer Space Treaty and the Moon Treaty promote a legal regime seemingly inhospitable to the commercialization of outer space. However, the two treaties do not prohibit the commercialization of outer space outright. Rather, they resist private ownership and appropriation, and even that resistance is not absolute. Ultimately, the two treaties do permit the private ownership and appropriation necessary to commercialize space, so long as international interests are given their due consideration. ${ }^{61}$

As a general observation, the Outer Space Treaty is steeped in the rhetoric of the "common interest of all mankind," especially expressing the concern that one part of "all mankind" - the less-developed nations - will be left out of the exploration and use of outer space while the other part of "all mankind" - the developed nations will reap all the rewards of exploiting outer space. Specifically, the Treaty declares that the exploration and use of outer space is to be conducted "for the benefit and in the interests of all countries... and shall be the province of all mankind."

To that end, outer space is to "be free for exploration and use by all States without discrimination of any kind, on a basis of equality and in accordance with international law, and there shall be free access to all areas of celestial bodies."

Given the principle of "freedom of access," it is little surprise that neither outer space nor celestial bodies are "subject to national appropriation." However, this does not directly address non-national appropriations, i.e. supra-national activities by the international community or sub-national activities by individuals. As to sub-national activities, the signatory states are required to "bear international responsibility for national activities in outer space" and on celestial bodies, which includes activities conducted by governmental bodies, non-governmental entities, or both. If the activities are conducted by non-governmental entities, then the appropriate state must authorize and continuously supervise such activities. However, beyond authorization and supervision, there is no indication as to what this "responsibility" means for the extent of permitted sub-national appropriation.

The Moon Treaty generally echoes the Outer Space Treaty, but it is also more extensive. The Moon Treaty recognizes "the benefits which may be derived from the exploitation of the natural resources of the Moon and other celestial bodies," and it protects those natural resources with rhetoric more potent than a common "interest." To wit, the Moon Treaty declares that those natural resources "are the common heritage of mankind." Is "heritage" exploitable? If so, who can exploit it, "mankind"? How does an ideal like "mankind" exploit resources? It would appear from the text of the Moon Treaty that "heritage" is exploitable only by "mankind" and that "mankind" is roughly translated into "international consensus."That is to say, the Moon Treaty establishes a default rule generally prohibiting any exploitation of the natural

${ }_{61}$ Zach Meyer, Private Commercialization of Space in an International Regime: A Proposal for a Space District, 30 Northwestern Journal of International Law \& Business 241 (2010). 
resources of any celestial body in the solar system other than Earth, and then provides for two exceptions based on international consensus. First, celestial bodies in the solar system other than Earth and the moon are no longer subject to the restrictions of the Moon Treaty if contrary "specific legal norms enter into force with respect to any of these celestial bodies." Second, if an appropriate international regime is created, then exploitation of the natural resources of celestial bodies may proceed.

According to the Moon Treaty, an appropriate international regime for regulating the exploitation of celestial natural resources need only fulfill four purposes: (1) "the orderly and safe development of the natural resources"; (2) "the rational management of those resources"; (3) "the expansion of opportunities in the use of those resources"; and (4) "[a]n equitable sharing" of the benefits of those resources giving "special consideration" to the "interests and needs of the undeveloped countries" and also "the efforts of those countries which have contributed either directly or indirectly to the exploration of the Moon."That international regime is supposed to be established "as such exploitation is about to become feasible."

In synthesis, the Outer Space Treaty and the Moon Treaty do not prohibit private property rights or forbid exploitation of natural resources in space. The Outer Space Treaty only outright prohibits "national appropriation," not supra- or sub-national appropriation, and requires that outer space be explored and used to benefit the interests of "all mankind." The principle of "freedom of access" does not prohibit private property rights or exploitation either, because there is no indication of the specified level of access - it could be free access to claim the property within an international regime or free access for scientific investigation, or perhaps it means the absence of a right to exclude. The first interpretation of "free access" is perhaps best in light of the Moon Treaty, because that treaty openly recognizes the benefits inherent in the exploitation of natural resources in space and even desires such exploitation. Thus, the two treaties together simply resist unilateral appropriation or exploitation. Instead, the two treaties envision a regime, created by international consensus, which will regulate such exploitation with due regard for the interests of not only developed nations but also undeveloped nations.

Thus, according to the thoughts expressed above, private commercial space enterprises probably can appropriate outer space and celestial bodies, but only in certain circumstances. While the Outer Space Treaty generally prohibits such appropriation, that prohibition is limited to "national" appropriation. Similarly, the Moon Treaty, where applicable, prohibits appropriation unless executed according to an international regime. The two treaties are policing not against appropriation per se, but against unilateral appropriation contrary to international interests.

A private commercial space enterprise can exploit the resources of the moon, and eventually other celestial bodies in the solar system, provided that the enterprise does so according to an appropriately established international regime. The Moon Treaty permits the exploitation of the natural resources of the celestial bodies in 
our solar system provided that an appropriate international regime governs the process. For the moon, the most important requirement of such a regime is that there be an "equitable sharing" between developed active states and undeveloped passive states. For other celestial bodies, there need only be "specific legal norms" in place regarding the body. So long as an international consensus is established, private commercial space enterprises can indeed exploit the natural resources of the moon and other celestial bodies.

In our view, however, both points of view on the matter of appropriation in space could exist and criticizing the Outer Space Treaty and the Moon Treaty for their ambiguity is justified. Yet, the very substance and idea of law that was laid down in these treaties should be taken into consideration. And this idea of law was not in favor of national commercialization in space.

\section{Conclusion}

In the field of space activities the commercialization process is actively developing. For objective reasons, this process could not be taken into account during the drafting and adoption of major international treaties. In this regard, some questions remain open, as such they require a speedy settlement. We distinguish the following issues that merit special attention.

To begin with, it is necessary to include legal persons carrying out activities in outer space. The fundamental international agreements on outer space do not contain an explicit prohibition against private operations in space nor do they regulate outer space commercial use issues. Responsibility for those kinds of activities is left solely with the state. It seems that the modernization of space law at the international level on the aspect considered is seen as Outer Space Treaty amendments on including legal persons in the list of international space law subjects and the determination of their legal status.

We propose that this subject be specified at the national level on the assumption of the balance of public and commercial interests. We consider it appropriate to impose responsibility on the persons owning the space object as the source of increased danger within the framework of national civil proceedings. At the same time, fixing responsibility on private organizations according to domestic law, the legal entities' insurance should be provided for as well as the limits of compensation.

Also, the exploitation of space brings the hazard of inflicting harm on third parties, which could evoke civil liability for a guilty party. Up to the present time, as a result of space activities or rather failures during space activities, hundreds of people have been killed, not to mention huge financial losses incurred. To protect oneself against claims, it is of course possible to purchase third-party liability insurance for space losses. The need to procure third-party liability insurance is based on protection against financial claims resulting from certain fundamental principles of international space law. 
Thus far there have been only a few cases of third-party liability for space losses. It should also be noted that there has never been a substantial claim on a space liability insurance policy. It remains to be seen whether this type of coverage would remain available if a major accident was to occur. The trouble is that fifty years have passed since the establishment of the major international documents in the field of international law. Yet the faultfinding mechanism is not clearly determined. What is more important is that relations between states do occur beyond the atmosphere of the Earth, and this is exactly where international law lacks proper liability regulation.

Additionally, there is a lack of order and clarification in respect of the search for minerals and extraction processes in outer space. We share the opinion that the state has no right to claim sovereignty or sovereign rights over the exploration and production of mineral resources in outer space (national appropriation). These provisions should be fixed in the Outer Space Treaty (by making appropriate amendments) in such a way that would not allow for a double interpretation.

At the same time, in relation to the question of whether or not there is any room for the exercise of some form or degree of superior authority, jurisdiction, use or occupation in outer space, the answer would seem to be in the affirmative, since the Moon Treaty prohibits the exercise of such authority, use or occupation only if it amounts to national appropriation. Under such interpretation, the temporary use of a celestial resource without its transformation or deterioration may be permissible, whereas the consumption or destruction of such a resource may not be.

Furthermore, insofar as the exercise of authority is concerned, the state on whose registry an object launched into space is carried must retain jurisdiction and control over such object, and over its personnel, while in outer space or on a celestial body. The Moon Treaty also makes it clear that states will be internationally responsible for national activities in outer space, including the moon and other celestial bodies, irrespective of whether such activities are carried out by governmental bodies or non-governmental entities. In fact, the activities of non-governmental entities require authorization and continuing supervision by the state concerned. The fact that some measure of at least temporary exclusive jurisdiction may be exercised over a particular area on the moon or other celestial bodies, including a space station and its adjacent elements, is also apparent from Art. XII of the Treaty, which makes access by representatives of a foreign state contingent on reciprocity.

\section{References}

Baslar K. The Concept of the Common Heritage of Mankind in International Law (Dordrecht, The Netherlands: Martinus Nijhoff, 1998).

Diederiks-Verschoor I.H.Ph. \& Kopal V. An Introduction to Space Law ( $3^{\text {rd }}$ ed., Alphen aan den Rijn: Kluwer Law International, 2008). 
Fasan E. The Meaning of the Term "Mankind" in Space Legal Language, 2 Journal of Space Law (1974).

Gouldner A.W. The Norm of Reciprocity: A Preliminary Statement, 25(2) American Sociological Review (1960).

Harn N. Commercial Mining of Celestial Bodies: A Legal Roadmap, 27 Georgetown Environmental Law Review (2014).

Hertzfeld H.R. A Roadmap for a Sustainable Space Legal Regime (Apr. 9, 2017), available at https://www.gwu.edu/ spi/assets/docs/Hertzfeld-IISL\%20PaperRevision\%2011-30-2012.pdf.

Jakhu R. Iridium-Cosmos Collision and Its Implications for Space Operations in Yearbook on Space Policy: 2008/2009 (K.-U. Schrogl et al. (eds.), Wien and New York: Springer, 2010).

Jakhu R. Legal Issues Relating to the Global Public Interest in Outer Space, 32 Journal of Space Law (2006).

Lachs M. The Law of Outer Space (Leiden: Sijthoff, 1972).

Lee R. Law and Regulation of Commercial Mining of Minerals in Outer Space (New York: Springer Science \& Business Media, 2012).

Lysén G. State Responsibility and International Liability of States for Lawful Acts: A Discussion of Principles (Gothenburg, Sweden: lustus Förlag, 1997).

Manikowski P. Examples of Space Damages in the Light of International Space Law, 1(1) The Poznań University of Economics Review (2006) (Apr. 4, 2017), also available at http://www.ebr.edu.pl/pub/2006_1_54.pdf.

McCarthy D.R. \& Fluck M. The Concept of Transparency in International Relations: Towards a Critical Approach, 23(2) European Journal of International Relations (2017).

Mejia-Kaiser M. Collision Course: 2009 Iridium Cosmos Crash, Published in the Proceedings of the Fifty-Second Colloquium on the Law of Outer Space (2009).

Meyer Z. Private Commercialization of Space in an International Regime: A Proposal for a Space District, 30 Northwestern Journal of International Law \& Business (2010).

$\mathrm{Ng}$ N. Fences in Outer Space: Recognising Property Rights in Celestial Bodies and Natural Resources, 7 The Western Australian Jurist (2016).

Paris F. \& Ghei N. The Role of Reciprocity in International Law, 36(1) Cornell International Law Journal (2003).

Pocar F. An Introduction to the PCA's Optional Rules for Arbitration of Disputes Relating to Outer Space Activities, 38 Journal of Space Law (2012) (Apr. 5, 2017), also available at http://www.spacelaw.olemiss.edu/jsl/pdfs/supplements/pocar.pdf.

Porras D.A. Comment the "Common Heritage" of Outer Space: Equal Benefits for Most of Mankind, 37(1) California Western International Law Journal (2006).

Robinson J. \& Silhan V. Securing Outer Space: A Major Global Challenge, 4 Science for Population Protection (2012).

Tan D. Towards a New Regime for the Protection of Outer Space as the "Province of All Mankind," 25(1) Yale Journal of International Law (2000). 
Vlasic I.A. The Space Treaty: A Preliminary Evaluation, 55(2) California Law Review (1967).

von der Dunk F.G. Liability Versus Responsibility in Space Law: Misconception or Misconstruction?, Published in the Proceedings of the Thirty-Fourth Colloquium on the Law of Outer Space (1992).

Wallace J. \& Wild S.E. Webster's New World Law Dictionary (Hoboken, NJ:Wiley, 2010). Welly N.D. Enlightened State-Interest - A Legal Framework for Protecting the "Common Interest of All Mankind" from Hardinian Tragedy, 36 Journal of Space Law (2010).

Zedalis R. \& Wade C. Anti-Satellite Weapons and the Outer Space Treaty of 1967, 8 California Western International Law Journal (1978).

\section{Information about the authors}

Marina Lits (Tyumen, Russia) - Assistant Professor, Department of Theory and History of State and Law, International Law, Institute of State and Law, Tyumen State University (38 Lenina St., Tyumen, 625003, Russia; e-mail: intlow@list.ru).

Sergei Stepanov (Tyumen, Russia) - PhD Student, Department of Theory and History of State and Law, International Law, Institute of State and Law, Tyumen State University (38 Lenina St., Tyumen, 625003, Russia; e-mail: sergey-u29@mail.ru).

Anna Tikhomirova (Tyumen, Russia) - Master's Student, Institute of State and Law, Tyumen State University (38 Lenina St., Tyumen, 625003, Russia; e-mail: yinxyang3@gmail.com). 